\title{
Short-term effects of FSH in vitro on granulosa cells of individual sheep follicles
}

\author{
D. Monniaux \\ INRA, Station de Physiologie de la Reproduction, Nouzilly, 37380 Monnaie, France
}

\begin{abstract}
Summary. In Romanov ewes at Day 13 or 14 of the cycle, granulosa cells originating from individual follicles were studied in short-term incubations for aromatase activity and thymidine incorporation. The study was performed on 76 follicles of different sizes (2-7 mm diameter) and degree of atresia, as assesed by histological examination of smears of granulosa cells. As atresia progressed, the labelling index and aromatase activity of granulosa cells decreased. In normal follicles, when follicular diameter increased, the labelling index decreased, while aromatase activity of granulosa cells and oestradiol-17 $\beta$ concentration in follicular fluid increased. There was a negative relationship between oestradiol concentration in follicular fluid and the labelling index of granulosa cells in vitro $\left(r_{\mathrm{s}}=-0.75 ; P<0.01\right)$, suggesting an inverse relationship between growth and differentiation of granulosa cells in normal sheep follicles.

In normal small and medium-sized follicles $(2-6 \mathrm{~mm})$, incubation with FSH $(100 \mathrm{ng} / \mathrm{ml})$ for $2 \mathrm{~h}$ increased significantly the labelling index of granulosa cells. In normal medium-sized follicles $(4-6 \mathrm{~mm})$, incubation with FSH $(50 \mathrm{ng} / \mathrm{ml})$ for $1 \mathrm{~h}$ decreased the aromatase activity of granulosa cells. From these results, it is suggested that FSH acts mainly on cells in the G1 phase of the cell cycle, which are steroidogenically active, and makes them move into the $\mathrm{S}$ phase where their steroidogenic activity is temporarily inhibited.
\end{abstract}

\section{Introduction}

In the sheep as in other mammalian species, growth of antral follicles involves cytodifferentiation of granulosa cells characterized by marked biochemical changes. An increased aromatization of androgens to oestrogens during terminal follicular growth has been clearly established (McNatty et al., 1979; Tsonis et al., 1984), while reduced aromatase activity in granulosa cells is associated with atresia (Moor, 1977; Moor et al., 1978; McNatty, 1981; Carson et al., 1981; Tsonis et al., 1984). Histological examination of ovaries indicates that, in the ewe, the mitotic index of granulosa cells of follicles larger than $1 \mathrm{~mm}$ in diameter decreases during terminal follicular growth (Turnbull et al., 1977). These results, taken together, suggest that, while differentiating, granulosa cells loose their ability to divide, but no direct relationship between the two phenomena has been clearly established.

Numerous investigations in different mammalian species have demonstrated that granulosa cells have a specific requirement for FSH in order to differentiate during the preovulatory stage. It is well established that FSH induces the synthesis and secretion of proteoglycans and plasminogen activator, the appearance of LH and prolactin receptors, and the ability for steroid synthesis (for review, see Richards, 1980; Dorrington et al., 1983; Hsueh et al., 1984). In the ewe, an increase in aromatase activity per cell induced by FSH has been observed in vitro by Moor (1977) and McNatty (1982) in long-term incubations of granulosa cells ( $48 \mathrm{~h}$ or longer). Another type of effect of FSH on granulosa cells, suggested by various investigations in different mammalian species, is the stimulation of follicular growth by enhancing granulosa cell multiplication. Injection of FSH in 
vivo produces an increase in incorporation of $\left[{ }^{3} \mathrm{H}\right]$ thymidine into DNA and in the labelling index in granulosa cells of mice (Pedersen, 1972) or rats (Rao et al., 1978; Peluso \& Steger, 1978). In vitro, a direct mitogenic action for FSH has been proposed (mouse: Ryle, 1969, 1972; human: McNatty \& Sawers, 1975; pig: Hammond et al., 1982). However, this effect has not been confirmed by some authors (cow: Savion et al., 1981; rat: Orly et al., 1980), who have found instead that serum growth factors seem important for granulosa cell proliferation. In the sheep, the effect of FSH on $\left[{ }^{3} \mathrm{H}\right]$ thymidine incorporation in vivo or in vitro has not yet been studied.

The aims of this work were to study the relationships between proliferation and differentiation in granulosa cells of sheep follicles as well as the action of FSH on these phenomena. Because of the large variability existing between normal follicles of the same size for physiological measures such as aromatase activity (Tsonis et al., 1984), the study was undertaken on individual follicles.

\section{Materials and Methods}

\section{Experimental design}

Cyclic Romanov ewes were synchronized with a progestagen-PMSG treatment (intravaginal fluorogestone acetate sponges, $40 \mathrm{mg}$, and PMSG, 300 i.u., at sponge removal; Cognié et al., 1970). Animals were ovariectomized 15 days after PMSG injection, i.e. at Day 13 or 14 of the new cycle as determined by detection of receptivity. Blood samples were obtained every day between PMSG injection and ovariectomy; plasma was collected and stored at $-20^{\circ} \mathrm{C}$ until assayed for progesterone. On the day of ovariectomy (Day 13 or 14 of the cycle), blood samples were taken every 15 min during the $3 \mathrm{~h}$ before operation; after storage at $-20^{\circ} \mathrm{C}$, plasma samples were assayed for $\mathrm{LH}$ and FSH, as described below.

\section{Isolation of follicles, follicular fluid and granulosa cells}

After ovariectomy, ovaries were quickly placed in Medium B2 (Menezo, 1976, 1985) and transported on ice to the laboratory. Individual follicles $(n=76$; diameter $\geqslant 2 \mathrm{~mm})$ were dissected and measured with a millimeter scale. Dissection of all the follicles was performed within $1 \mathrm{~h}$ after ovariectomy. Follicular fluid of each follicle was aspirated with a 26-gauge needle, put in a glass tube and stored at $-20^{\circ} \mathrm{C}$ until assayed for oestradiol-173.

After the antral fluid was removed, the collapsed follicle was slit open in $250 \mu 1$ Medium B2. Granulosa cells were removed by scraping gently and repeatedly the interior surface of the follicle wall with a platinum loop (McNatty et al., 1979). The granulosa-cell suspension was homogenized by aspirating it several times with a flame-polished, siliconized Pasteur pipette. A sample of $20 \mu \mathrm{l}$ was removed and used for follicle quality determination as described below. The remaining cell suspension was transferred to a glass tube containing $500 \mu \mathrm{l}$ Medium B2, centrifuged ( $300 \mathrm{~g}$ ) for $7 \mathrm{~min}$ and resuspended in $250 \mu \mathrm{l}$ Medium B2. An aliquant of this final suspension of granulosa cells was counted using a haemocytometer; cell viability was determined after vital staining with trypan blue $(0 \cdot 125 \%$, final concentration). On each cell suspension, the 'thymidine test' and the 'aromatase test' were performed as described below.

\section{Determination of follicle quality}

An aliquant of the homogenized suspension of granulosa cells was transferred to a glass tube containing $500 \mu l$ Medium B2, centrifuged as described above and resuspended in $100 \mu$ glutaraldehyde ( $3 \%$ in PBS); after fixation for $1-2 \mathrm{~h}$ at room temperature, smears were prepared by cytocentrifugation on histological slides (Watson, 1966). The quality of the follicle was assessed by microscopic examination of the Feulgen-stained cell preparations.

In a preliminary study, we analysed smears of granulosa cells from follicles with various stages of atresia; the degree of atresia was determined for each follicle by classic histological study of a piece of follicular wall, according to the criteria of Brand \& De Jong (1973) and Turnbull et al. (1977).

Mitosis was frequent in smears of granulosa cells originating from histologically normal follicles; in early atretic follicles, granulosa cells were slightly pycnotic with persistence of mitosis; definitely atretic follicles were characterized by many pycnotic bodies and no mitosis in granulosa cells; late atretic follicles were characterized by rare 'normal' granulosa cells and a great majority of pycnotic bodies (Fig. 1).

\section{'Thymidine test'}

Two aliquants of cell suspension (20000-200 000 viable cells) were transferred to glass tubes containing Medium B2 prepared without thymidine, centrifuged, and resuspended in $500 \mu \mathrm{l} \mathrm{Medium} \mathrm{B2}$ without thymidine but supple- 


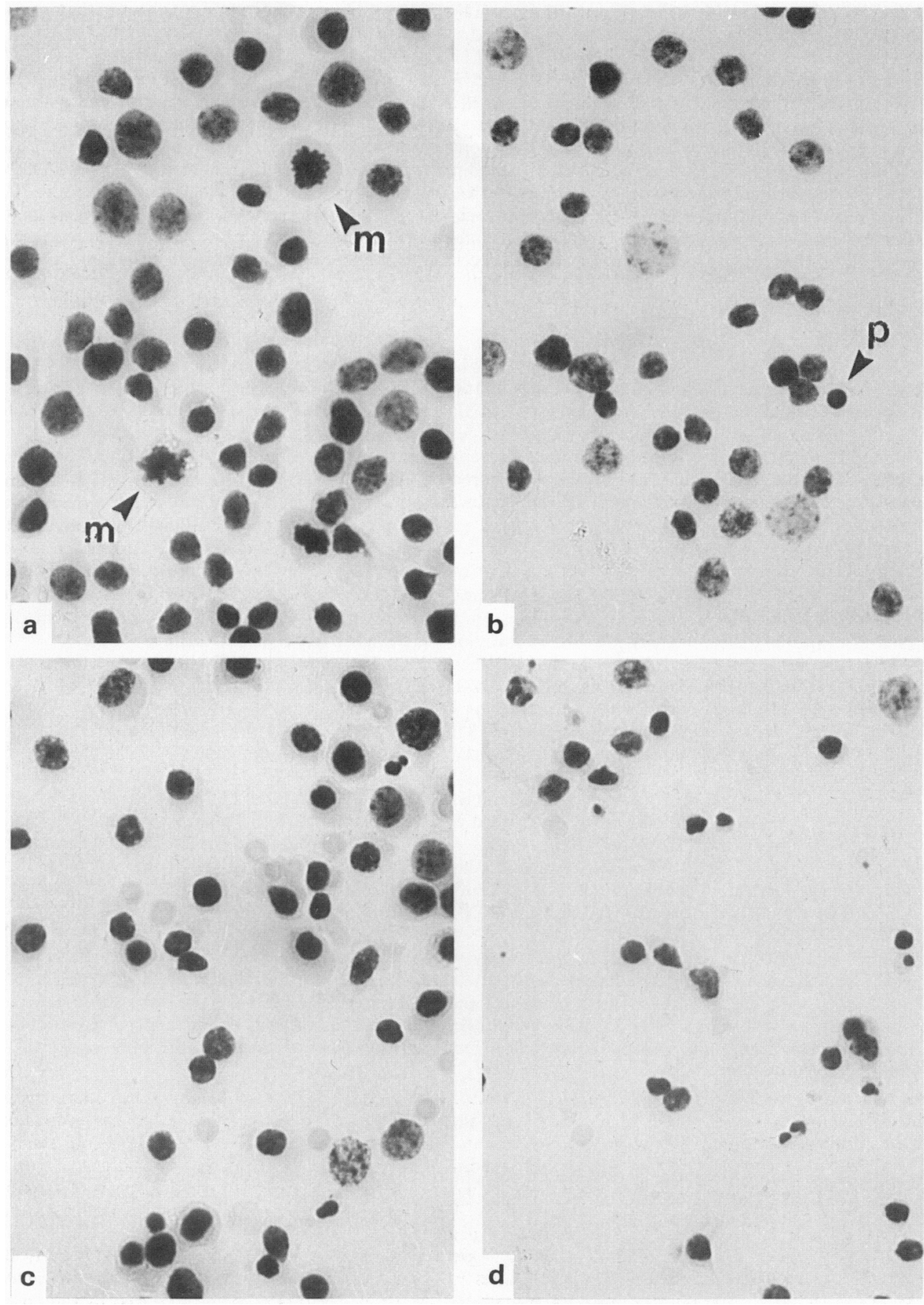

Fig. 1. Granulosa cells isolated from (a) a normal follicle of $3 \mathrm{~mm}$ diameter, with some cells showing mitosis (m); (b) an early atretic follicle of $4 \mathrm{~mm}$ diameter: cells have a normal appearance, mitosis can be seen but some pycnosis (p) is observed; (c) a definitely atretic follicle of $7 \mathrm{~mm}$ diameter: there are many pycnotic bodies and but no mitotic activity; and (d) a late atretic follicle of $4 \mathrm{~mm}$ diameter: there are abundant pycnotic bodies and degenerating cells. 
mented with $\left[{ }^{3} \mathrm{H}\right]$ thymidine $(5 \mu \mathrm{Ci} / \mathrm{ml}$; sp. act. $25 \mathrm{Ci} / \mathrm{mmol}$; C.E.A., Saclay, France). In one of the 2 aliquants, FSH $(100 \mathrm{ng} / \mathrm{ml})$ was added. For all the experiments, purified ovine FSH, CY 1115 (FSH activity $=22.2 \times$ activity of NIH-FSH-S1; LH activity $=0.02 \times$ activity of NIH-oLH-S21; TSH activity $=0.002 \times$ activity of NIH-TSH-II) was used. Cells were incubated in an humidified $95 \%$ air $5 \% \mathrm{CO}_{2}$ incubator at $37^{\circ} \mathrm{C}$ for $2 \mathrm{~h}$. At the end of incubation, $1 \mathrm{ml}$ Medium B2 (with thymine) was added to the tubes. After centrifugation, cells were resuspended in $1 \mathrm{ml}$ Medium B2 for washing, centrifuged again, and fixed with glutaraldehyde; smears were prepared as described above. One smear was prepared with cells incubated with FSH, and one smear with cells incubated without FSH. After Feulgen staining, slides were prepared for autoradiography; after dipping in Ilford $\mathrm{K} 5$ emulsion diluted $1 / 1(\mathrm{v} / \mathrm{v})$ with distilled water, they were air dried and exposed for 10 days at $4^{\circ} \mathrm{C}$, then developed and fixed by classical procedures. After mounting, slides were examined microscopically. For each smear all the labelled cells were counted, and the total number of cells was calculated from an estimate of the cellular density made using a circular reticule (10 measurements per smear). Then the labelling index (number of labelled cells/total number of viable cells) was calculated.

\section{'Aromatase test'}

Optimal aromatase assay conditions for sheep granulosa cells have been established by Tsonis et al. (1984). Based on these data, 3 aliquants of cell suspension (40000-200 000 viable cells) were transferred to glass tubes containing $500 \mu \mathrm{l} \mathrm{Medium} \mathrm{B2} \mathrm{(final} \mathrm{volume)} \mathrm{and} \mathrm{incubated} \mathrm{for} 1 \mathrm{~h}$ at $37^{\circ} \mathrm{C}$ under an atmosphere of $95 \%$ air $/ 5 \% \mathrm{CO}_{2}$; in one tube, there was no hormonal supplementation; in the second, testosterone $\left(10^{-7} \mathrm{M}\right)$ was added; in the third, testosterone $\left(10^{-7} \mathrm{M}\right)$ and $\mathrm{FSH}(50 \mathrm{ng} / \mathrm{ml})$ were added. Incubations were terminated by adding $1 \mathrm{ml}$ Medium B2 and immediately centrifuging the tubes; individual supernatants were stored at $-20^{\circ} \mathrm{C}$ until assayed for oestradiol-17 $\beta$. Aromatase activity was expressed as pg oestradiol- $17 \beta / 10^{5}$ viable cells $/ \mathrm{h}$.

\section{Hormone radioimmunoassays}

Progesterone in plasma was assayed with the method of Saumande et al. (1985) which had a sensitivity of $0.1 \mathrm{ng} / \mathrm{ml}$. The intra- and inter-assay coefficients of variation were respectively $11 \%$ and $12 \%$.

$L H$ in plasma was assayed with the method of Pelletier (1972). The sensitivity of the assay was $0.06 \mathrm{ng} \mathrm{LH} \mathrm{CY}$ $1051 / \mathrm{ml}$ plasma $(1 \mathrm{mg} \mathrm{LH} \mathrm{CY} 1051=2 \cdot 1 \mathrm{mg}$ NIH-oLH-S1). LH concentrations were measured in all plasmas in the same assay and the intra-assay coefficient of variation was $9 \%$.

FSH in plasma was assayed with the method of Blanc \& Poirier (1979) which had a sensitivity of $2.4 \mathrm{ng}$ NIH-FSH-S3/ml plasma. FSH concentrations were measured in all plasmas in the same assay and the intra-assay coefficient of variation was $8 \%$.

Oestradiol-17 $\beta$ was assayed with the technique of Thibier \& Saumande (1975) with some modifications as follows. Follicular fluids $(3-50 \mu \mathrm{l})$ were diluted with $1 \mathrm{ml}$ distilled water and extracted with $10 \mathrm{ml}$ ethyl acetate-cyclohexane $(1: 1, v: v)$; recovery after extraction was $86 \pm 0 \cdot 2 \%$ (mean \pm s.d.). The extracted follicular fluid diluted parallel to the standard curve. The sensitivity of the assay $(1.5 \mathrm{pg})$ did not permit detection of oestradiol when the volume of follicular fluid was $<5 \mu$. Oestradiol concentrations were measured in all follicular fluids in the same assay. The antiserum used was shown previously to be specific for oestradiol-17ß (Dray et al., 1971) and there was no cross-reaction $>1 \%$ with other steroids.

For supernatants of cell incubations, a direct assay was performed in duplicate on $100 \mu$ Medium B2. The standard curve was made in medium and found to be parallel to a standard curve in buffer. The limit of detection was unchanged and, with the conditions used in the aromatase test $\left(10^{5}\right.$ viable cells per tube, final volume of medium $=1.5 \mathrm{ml}$ ), all the values below $25 \mathrm{pg} / 10^{5}$ viable cells $/ \mathrm{h}$ were not significantly different from 0 . Oestradiol-17 concentrations were measured in all supernatants of cell incubations in the same assay and the intra-assay coefficient of variation was $6 \%$.

\section{Statistical methods}

Because the data were not normally distributed, non-parametric statistics were used. The Kruskal-Wallis analysis of variance was used to test the effect of atresia or follicular size on the different measures. The effects of FSH were tested using the paired test of Wilcoxon. Tests of association were made using the Spearman rank correlation coefficient $\left(r_{\mathrm{s}}\right)$.

\section{Results}

\section{Endocrine status of the animals}

Eight ewes were ovariectomized at Day 13 or 14 of the cycle. Plasma progesterone concentrations were high $(8 \cdot 8 \pm 2 \cdot 1$ (s.d.) $\mathrm{ng} / \mathrm{ml})$ on the day of ovariectomy. During the $3 \mathrm{~h}$ before 
surgery, no significant fluctuations in plasma FSH concentrations could be detected in any of the animals $(5.7 \pm 1.7 \mathrm{ng} / \mathrm{ml})$. LH concentrations were uniformly low (basal: $0.12 \pm 0.01 \mathrm{ng} / \mathrm{ml}) ; 2$ animals only displayed $1 \mathrm{LH}$ pulse $(1 \mathrm{ng} / \mathrm{ml}$ and $1.9 \mathrm{ng} / \mathrm{ml})$ during the $3 \mathrm{~h}$ before ovariectomy. No hormone value could be related to any FSH-induced cellular response in vitro.

\section{Effect of atresia on sensitivity of granulosa cells to FSH in vitro}

Altogether 76 follicles of different sizes $(2-7 \mathrm{~mm})$ and degrees of atresia were studied for aromatase activity and thymidine incorporation during short-term incubations with or without FSH.

Atresia was defined by histological criteria based on analysis of smears of granulosa cells (see 'Materials and Methods') of individual follicles. As atresia progressed, the viability of granulosa cell suspensions ( $\%$ of viable cells) decreased (Kruskal-Wallis test, $\mathrm{H}=17 \cdot 13 ; P<0.001$ ) as did concentration of oestradiol in follicular fluid $(\mathrm{H}=9.85 ; P<0.02)$ (Table 1), and the labelling index of granulosa cells incubated without FSH $(\mathrm{H}=49.78 ; P<0.001)$ and with FSH $(\mathrm{H}=43.51$; $P<0 \cdot 001$ ) (Table 2).

Table 1. Effect of atresia, as defined by histological examination of smears of granulosa cells, on oestradiol concentrations in follicular fluid and viability of granulosa cell suspensions

\begin{tabular}{|c|c|c|c|c|}
\hline & $\begin{array}{l}\text { Normal } \\
\text { follicles }\end{array}$ & $\begin{array}{l}\text { Early atretic } \\
\text { follicles }\end{array}$ & $\begin{array}{c}\text { Definitely } \\
\text { atretic follicles }\end{array}$ & $\begin{array}{l}\text { Late atretic } \\
\text { follicles }\end{array}$ \\
\hline $\begin{array}{l}\text { Oestradiol conc.* in follicular fluid } \\
\text { (ng/ml) }\end{array}$ & ${ }_{(15)}^{4.55 \pm} 1.87$ & $\frac{3 \cdot 40 \pm}{(10)} 2.08$ & $1.99 \underset{(8)}{ \pm} 1.80$ & $1.49 \pm \frac{ \pm}{(6)} 2 \cdot 39$ \\
\hline Viability of granulosa cells $\dagger(\%)$ & $53 \cdot 5 \pm 12 \cdot 6$ & $41 \cdot 7 \underset{(20)}{ \pm 15 \cdot 6}$ & $43.8 \underset{(19)}{ \pm 10.8}$ & $29 \cdot 5 \underset{(12)}{ \pm 18 \cdot 1}$ \\
\hline
\end{tabular}

*Detectable only in follicles with a volume of follicular fluid $>5 \mu 1$.

Assessed by trypan-blue exclusion test.

Values are mean \pm s.d. for the no. of follicles in parentheses.

Table 2. Effect of FSH in vitro on the labelling index of granulosa cells of normal and atretic follicles

\begin{tabular}{lcccc}
\hline & $\begin{array}{c}\text { Normal } \\
\text { follicles }\end{array}$ & $\begin{array}{c}\text { Early atretic } \\
\text { follicles }\end{array}$ & $\begin{array}{c}\text { Definitely } \\
\text { atretic follicles }\end{array}$ & $\begin{array}{c}\text { Late atretic } \\
\text { follicles }\end{array}$ \\
\hline $\begin{array}{l}\text { No. of follicles studied } \\
\text { Labelling index } \\
\text { (\% viable cells) } \\
\text { Without FSH }\end{array}$ & 25 & 20 & 19 & 11 \\
$\quad$ With FSH & $34 \cdot 4$ & $39 \cdot 6$ & & \\
& $(7 \cdot 6-75 \cdot 2)$ & $(3 \cdot 1-162 \cdot 4)$ & $(0 \cdot 5-17 \cdot 3)$ & $(0-6 \cdot 8)$ \\
& $47 \cdot 8 * *$ & $48 \cdot 6$ & $6 \cdot 6$ & $2 \cdot 7$ \\
& $(4 \cdot 2-122 \cdot 1)$ & $(1 \cdot 8-261 \cdot 9)$ & $(0 \cdot 8-23 \cdot 5)$ & $(0-7 \cdot 1)$ \\
\hline
\end{tabular}

$* * P<0.01$, compared with the group of cells incubated without FSH.

Values in parentheses indicate the ranges in each group.

The labelling index of granulosa cells was very variable amongst the individual follicles, normal or atretic, but the experimental design allowed comparison of the FSH-stimulated and the nonstimulated groups of cells by paired tests. In normal follicles, FSH significantly increased the labelling index of granulosa cells (Wilcoxon paired test; $T=26 ; P<0.01$ ); there was no significant increase in early atretic follicles (Table 2). 
The aromatase activity of granulosa cells was measured by incubating cells with testosterone as substrate. As atresia progressed, the aromatase activity of granulosa cells decreased; this was observed for cells incubated without FSH (Kruskal-Wallis test; $\mathrm{H}=28.55 ; P<0.001$ ) and with FSH $(\mathrm{H}=29.49 ; P<0.001)$ (Table 3 ). In normal follicles FSH significantly decreased the aromatase activity of granulosa cells (Wilcoxon paired test; $\mathrm{T}=70 ; P<0.05$ ); there was no significant decrease in early atretic follicles.

Table 3. Effect of FSH in vitro on the aromatase activity of granulosa cells of normal and atretic follicles

\begin{tabular}{|c|c|c|c|c|}
\hline & $\begin{array}{l}\text { Normal } \\
\text { follicles }\end{array}$ & $\begin{array}{l}\text { Early atretic } \\
\text { follicles }\end{array}$ & $\begin{array}{l}\text { Definitely } \\
\text { atretic follicles }\end{array}$ & $\begin{array}{l}\text { Late atretic } \\
\text { follicles }\end{array}$ \\
\hline No. of follicles studied & 24 & 16 & 15 & 5 \\
\hline \multicolumn{5}{|l|}{$\begin{array}{l}\text { Oestradiol secreted in medium } \\
\left(\mathrm{pg} / 10^{5} \text { viable cells } / \mathrm{h}\right)\end{array}$} \\
\hline Without hormonal supplementation & $\begin{array}{c}15 \cdot 6 \\
(2 \cdot 8-48 \cdot 4)\end{array}$ & $\begin{array}{c}13 \cdot 2 \\
(4 \cdot 2-30 \cdot 9)\end{array}$ & $\begin{array}{c}12 \cdot 1 \\
(4 \cdot 5-30 \cdot 0)\end{array}$ & $\begin{array}{c}8 \cdot 7 \\
(4 \cdot 5-10 \cdot 3)\end{array}$ \\
\hline With testosterone & $\begin{array}{c}486 \cdot 3 \\
(12 \cdot 5-2091 \cdot 6)\end{array}$ & $\begin{array}{c}182 \cdot 0 \\
(4 \cdot 7-744 \cdot 3)\end{array}$ & $\begin{array}{c}19 \cdot 7 \\
(5 \cdot 9-100 \cdot 8)\end{array}$ & $\begin{array}{c}12 \cdot 0 \\
(9 \cdot 3-17 \cdot 8)\end{array}$ \\
\hline With testosterone + FSH & $\begin{array}{c}416 \cdot 3^{*} \\
(18 \cdot 2-1691 \cdot 4)\end{array}$ & $\begin{array}{c}143 \cdot 1 \\
(5 \cdot 8-650 \cdot 8)\end{array}$ & $\begin{array}{c}20 \cdot 7 \\
(5 \cdot 8-108 \cdot 9)\end{array}$ & $\begin{array}{c}15 \cdot 3 \\
(8 \cdot 0-20 \cdot 8)\end{array}$ \\
\hline
\end{tabular}

$* P<0.05$, compared with the group of cells incubated without FSH and with testosterone.

Values in parentheses indicate the ranges in each group.

\section{Effect of follicular size on sensitivity of granulosa cells to FSH in vitro}

In normal follicles, oestradiol concentration in follicular fluid was positively related to follicular diameter $\left(r_{\mathrm{s}}=0.72 ; P<0.01\right)$ (Fig. 2). Three size classes of follicles were considered: small follicles with a diameter $2-<4 \mathrm{~mm}$, medium-sized follicles with diameter $4<6 \mathrm{~mm}$ and large follicles with diameter $6-<8 \mathrm{~mm}$. When follicular diameter increased, labelling index of granulosa cells of normal follicles decreased; this was observed for cells incubated without FSH (Kruskal-Wallis test; $\mathrm{H}=8.90, P<0.02)$ and with $\mathrm{FSH}(\mathrm{H}=11.20 ; P<0.01)$ (Fig. 3). FSH significantly increased the labelling index of granulosa cells of normal small (Wilcoxon paired test; $\mathrm{T}=2 ; P<0.01$ ) and medium-sized (Wilcoxon paired test; $\mathrm{T}=0 ; P<0.01$ ) follicles.

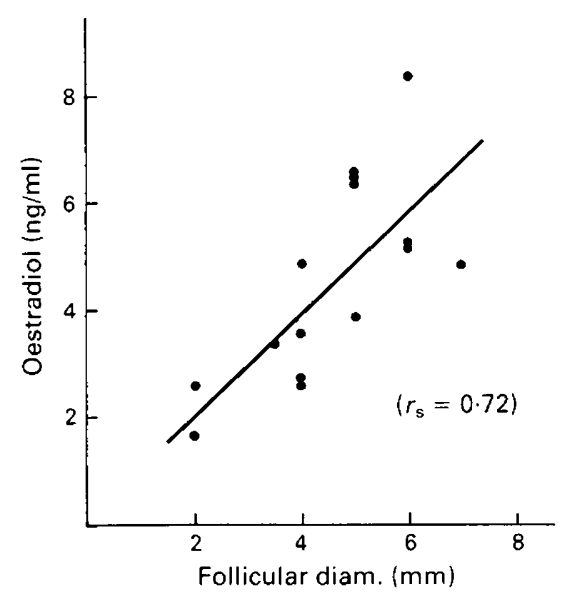

Fig. 2. Relationship between oestradiol-173 concentration in follicular fluid and follicular diameter in normal sheep follicles $(n=15)$. 


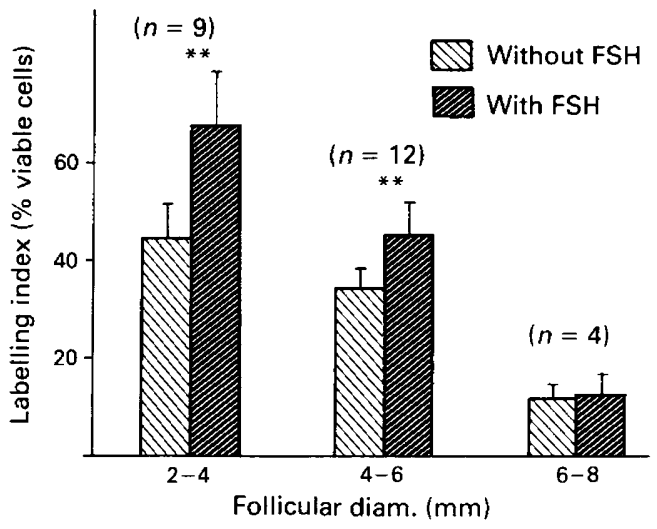

Fig. 3. Labelling index of granulosa cells isolated from normal follicles of different sizes; for each follicle, cells were incubated for $2 \mathrm{~h}$ with $\left[{ }^{3} \mathrm{H}\right]$ thymidine $(5 \mu \mathrm{Ci} / \mathrm{ml})$, with or without $\mathrm{FSH}$ $(100 \mathrm{ng} / \mathrm{ml})$; the percentage of labelled nuclei was estimated by histological analysis of smears after autoradiography. Values are mean $\pm \mathrm{s.d} .{ }^{* *} P<0.01$ compared with value for cells incubated without FSH.

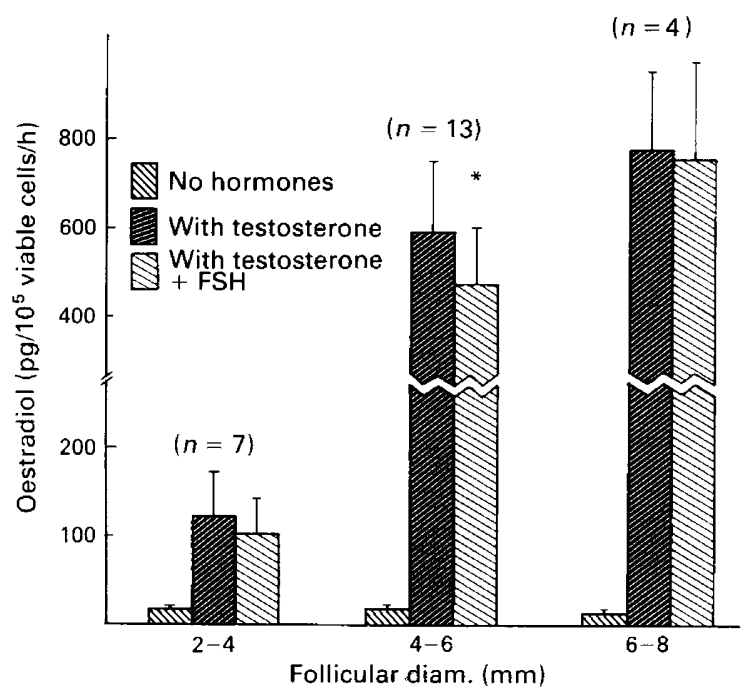

Fig. 4. Aromatase activity of granulosa cells isolated from normal follicles of different sizes; for each follicle, cells were incubated for $1 \mathrm{~h}$ with or without testosterone as substrate $\left(10^{-7} \mathrm{M}\right)$ and with or without FSH $(50 \mathrm{ng} / \mathrm{ml})$; oestradiol- $17 \beta$ secreted in culture medium was then measured by radioimmunoassay. ${ }^{*} P<0.05$; cells incubated with FSH and testosterone $v s$ cells incubated with testosterone only.

When follicular diameter increased, aromatase activity of granulosa cells of normal follicles increased; this was observed for cells incubated without FSH (Kruskal-Wallis test; $\mathrm{H}=9 \cdot 40$; $P<0.01)$ and with FSH $(\mathrm{H}=9.56 ; P<0.01)$ (Fig. 4). FSH significantly decreased the aromatase activity of granulosa cells of normal medium-sized $(4-<6 \mathrm{~mm}$ ) follicles (Wilcoxon paired test; $\mathrm{T}=12 ; P<0.05)$. 


\section{Relationship between growth and differentiation in granulosa cells}

When only normal follicles were considered, there was a significant positive relationship between oestradiol concentration in follicular fluid and aromatase activity of granulosa cells in vitro $\left(r_{\mathrm{s}}=0.73 ; P<0.01\right)$ (Fig. 5a). In normal follicles, therefore, oestradiol concentrations in follicular fluid would be indicative of the degree of differentiation of follicles. Furthermore, there was a significant negative relationship between oestradiol concentration in follicular fluid and labelling index of granulosa cells in vitro $\left(r_{\mathrm{s}}=-0.75 ; P<0.01\right)$ (Fig. 5b). These results indicate an inverse relationship between granulosa cell growth and differentiation in normal sheep follicles.

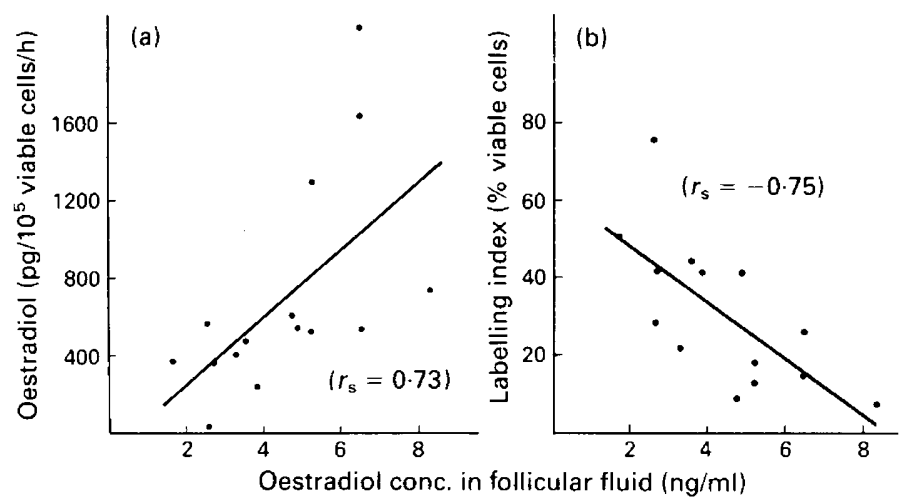

Fig. 5. Relationship between oestradiol- $17 \beta$ concentration in follicular fluid and (a) aromatase activity of granulosa cells incubated with testosterone $\left(10^{-7} \mathrm{M}\right)$ for $1 \mathrm{~h}$, and (b) labelling index of granulosa cells incubated with $\left[{ }^{3} \mathrm{H}\right]$ thymidine $(5 \mu \mathrm{Ci} / \mathrm{ml})$ for $2 \mathrm{~h}$.

\section{Discussion}

For investigation of the relationships existing between proliferation and differentiation in granulosa cells originating from sheep follicles of various sizes and quality, the rapid aromatase assay previously developed by Tsonis $e t$ al. (1984) and a thymidine incorporation test that has not previously been described were performed on each individual follicle. A new method for assessing atresia is also proposed. Tsonis et al. (1984) used two methods for the assessment of atresia, one morphological (Moor et al., 1978; Carson et al., 1979) and the other morphometric (McNatty, 1981, 1982), and pointed out the limitations of these two methods, which gave sometimes contradictory results and did not allow determination of the early stages of atresia. Our method consisted of examination of smears of granulosa cells, from an aliquant of a freshly prepared cell suspension. In a preliminary study, histological comparison with the status of a piece of follicular wall allowed classification of the quality of the follicles according to the presence of mitosis and/or pycnosis on the smears. With these criteria, a decrease in aromatase activity was observed as an early event in the atretic process and was supported by a decrease in concentrations of oestradiol-17 $\beta$ in follicular fluid (Tables 1 and 3). This was not found by Tsonis et al. (1984). However, with classic histological criteria, Kenney et al. (1979) for the horse and Brailly et al. (1981) for the human found that pycnosis generally precedes changes in steroidogenesis. Since the present methods yield similar results, they would be more sensitive than morphometric or morphological techniques in assessing atresia. Moreover, they are rapid and simple, and require only a small number of cells. However, even with these criteria of atresia, the labelling index was not decreased in early atretic follicles (Table 2); in classic histological studies (Turnbull et al., 1977), the mitotic index decreased in early 
atretic follicles, compared to normal ones. The differences with the present results could be attributed to differences in detecting early atresia in follicles, or to the technique of isolating granulosa cells, which could damage some cells and produce some additional pycnosis in smears. It is clear, however, that the mitotic index in the previous studies and the labelling index in the present study are quite variable within each category of follicle, clearly indicating the difficulty of all authors in assessing atresia.

When follicular size increases, the labelling index of granulosa cells of normal follicles decreases. No result of labelling with tritiated thymidine in granulosa cells has been reported previously in the ewe, but the present results confirm those of Turnbull et al. (1977) regarding the changes in mitotic index with follicular size. Moreover, they are in agreement with changes in labelling index with follicular size observed in rodents (Pedersen, 1970). The labelling index of granulosa cells with thymidine in vitro would therefore provide information on the growth characteristics of individual follicles in the sheep. The present results indicate that oestradiol concentrations in follicular fluid and aromatase activity per granulosa cell increase when follicular size increases. This is in agreement with results of McNatty (1982) for the ewe, McNatty et al. (1984) for the cow and Garzo \& Dorrington (1984) for the human, but Tsonis et al. (1984) did not observe any significant increase in aromatase activity per cell in follicles larger than $3.5 \mathrm{~mm}$ diameter in the ewe. I have no explanation for this discrepancy.

The present results display a significant negative correlation between the labelling index of granulosa cells and oestradiol concentrations in follicular fluid or aromatase activity of granulosa cells (Fig. 5). This inverse relationship between proliferation and differentiation of granulosa cells in follicles suggests that, in large follicles, more and more cells leave the cell cycle of replication and enter a G0 differentiated state. Using a theoretical two-phase model implying a proliferation phase and a differentiation phase, De Maertelaer \& Pottier (1985) found that cell proliferation and differentiation rates cannot be regulated solely by specific exogenous substances like hormones. Instead they postulated that an inhibitory signal produced by the differentiating cells acts on the rate of proliferation. This mechanism with 'chalone-like' inhibiting substances could help to explain changes observed in multiplication and differentiation of granulosa cells during terminal follicular growth.

The second aim of this work was to study the short-term effects of FSH on the labelling index and the aromatase activity of granulosa cells in follicles of different size and quality. In normal small and medium-sized follicles, incubation with FSH for $2 \mathrm{~h}$ increased significantly the labelling index of granulosa cells. A similar effect of FSH has been described previously for follicles of rodents after injection of FSH in vivo (Pedersen, 1972; Rao et al., 1978; Peluso \& Steger, 1978). Pedersen (1972) noticed an increase in labelling index in some follicles only $3 \mathrm{~h}$ after FSH injection; this result is in agreement with the short-term effect of FSH observed in this study in vitro for the ewe. It suggests that an early effect of FSH on granulosa cells would be that some proliferating cells leave the $\mathrm{G} 1$ phase and enter into the $\mathrm{S}$ phase. Further investigations are in progress to clarify this point.

Another short-term effect of FSH on granulosa cells is to decrease aromatase activity per cell in medium-sized normal follicles. In long-term incubations ( $24 \mathrm{~h}, 48 \mathrm{~h}$ or longer), Moon et al. (1975) for the rat, Moor (1977) for the ewe, and Moon et al. (1978) for the human and subsequently numerous other authors found that FSH increased aromatase activity in granulosa cells. This stimulation of differentiation by FSH was not observed in less than $24 \mathrm{~h}$, and it cannot therefore be compared to the short-term effect observed in this study. From the results on the short-term effect of FSH, I suggest that FSH acts mainly on steroidogenically active cells in the G1 phase and makes them move into the $S$ phase, where their steroidogenic activity is temporarily inhibited. In many types of cells, changes in metabolic activity, such as synthesis of RNA or proteins or enzymic activity, have been observed in different cell cycle phases (Vendrely et al., 1970; Darzynkiewicz, 1984). It is possible that, when granulosa cells enter into the $S$ phase, their aromatase activity is depressed by an unknown mechanism. In large follicles, many granulosa cells have left the cell cycle 
of replication and entered into a G0 differentiated state with a very high level of aromatase activity. No short-term effect of FSH was observed in granulosa cells of these follicles, suggesting that the differentiated cells in the G0 phase are unable to enter quickly into the $S$ phase as cells in the GI phase do. Further investigations are necessary to test these hypotheses and to understand the short-term effects of FSH on differentiation and proliferation of granulosa cells.

I thank M. Ottogalli and F. Lecomte for technical assistance; Dr Y. Combarnous for the purified FSH; and Dr J. C. Mariana for helpful discussions and comments.

\section{References}

Blanc, M.R. \& Poirier, J.C. (1979) A new homologous radioimmunoassay for ovine follicle stimulating hormone: development and characterization. Annls Biol. anim. Biochim. Biophys. 19, 1011-1026.

Brailly, S., Gougeon, A., MIlgrom, E., BomselHelmreich, O. \& Papiernik, E. (1981) Androgens and progestins in the periovulatory human follicle. Differences in the evolution of preovulatory, healthy non ovulatory and atretic follicles. J. clin. Endocr. Metab. 53, 128-134.

Brand, A. \& De Jong, W.H.R. (1973) Qualitative and quantitative micromorphological investigations of the tertiary follicle population during the oestrous cycle in sheep. J. Reprod. Fert. 33, 431-439.

Carson, R.S., Findlay, J.K., Burger, H.G. \& Trounson, A.O. (1979) Gonadotropin receptors of the ovine ovarian follicle during follicular growth and atresia. Biol. Reprod. 21, 75-87.

Carson, R.S., Findlay, J.K., Clarke, I.J. \& Burger, H.G. (1981) Estradiol, testosterone and androstenedione in ovine follicular fluid during growth and atresia of ovarian follicles. Biol. Reprod. 24, 105-113.

Cognié, Y., Mariana, J.C. \& Thimonier, J. (1970) Etude du moment d'ovulation chez la brebis normale ou traitée par un progestagène associé ou non à une injection de PMSG. Annls Biol. anim. Biochim. Biophys. 10, 15-24.

Darzynkiewicz, Z. (1984) Metabolic and kinetic compartments of the cell cycle distinguished by multiparameter flow cytometry. In Growth, Cancer and the Cell Cycle, pp. 249-278. Eds P. Skehan \& S. J. Friedman. The Humana Press, Clifton, New Jersey.

De Maertelaer, V. \& Pottier, D. (1985) Stability of cell populations in vivo. J. theor. Biol. 113, 299-310.

Dorrington, J.H., McKeracher, H.L., Chan, A.K. \& GoreLangton, R.E. (1983) Hormonal interactions in the control of granulosa cell differentiation. J. Steroid Biochem. 19, 17-32.

Dray, F., Terqui, M., Desfosses, B., Chauffournier, J.M., Mowszowicz, I., Kahn, D., Rombauts, P. \& Jayle, M.F. (1971) Propriétés d'immunosérums anti-17 $\beta$-oestradiol obtenus chez différentes espèces animales avec l'antigène 17ß-oestradiol-6-O-carboxyméthoxime-sèrum-albumine de boeuf. $C$.r.hebd. Séanc. Acad. Sci., Paris D 273, 2380-2383.

Garzo, V.G. \& Dorrington, J.H. (1984) Aromatase activity in human granulosa cells during follicular development and the modulation by follicle-stimulating hormone and insulin. Am. J. Obstet. Gynecol. 148, 657-662.
Hammond, J.M., Veldhuis, J.D., Seale, T.W. \& Rechler, M.M. (1982) Intraovarian regulation of granulosa cell replication. In Intraovarian Control Mechanisms, pp. 341-356. Eds S. J. Segal \& C. P. Channing. Plenum Press, New York.

Hsueh, A.J.W., Adashi, E.Y., Jones, P.B.C. \& Welsh, T.H. (1984) Hormonal regulation of the differentiation of cultured ovarian granulosa cells. Endocr. Rev. 5, 76-127.

Kenney, R.M., Condon, W., Ganjam, V.K. \& Channing, C.P. (1979) Morphological and biochemical correlates of equine ovarian follicles as a function of their state of viability or atresia. J. Reprod. Fert., Suppl. 27, 163-171.

MeNatty, K.P. (1981) Hormonal correlates of follicular development in the human ovary. Aust. J. biol. Sci. 34, 249-268.

McNatty, K.P. (1982) Ovarian follicular development from the onset of luteal regression in humans and sheep. In Follicular Maturation and Ovulation, pp. 1-18. Eds R. Rolland, E. V. van Hall, S. G. Hillier, K. P. McNatty \& J. Schoemaker. Excerpta Medica, Amsterdam.

McNatty, K.P. \& Sawers, R.S. (1975) Relationship between the endocrine environment within the Graafian follicle and the subsequent rate of progesterone secretion of human granulosa cells in vitro. $J$. Endocr. 66, 391-400.

NeNatty, K.P., Moore-Smith, D., Makris, A., Osathanondh, R. \& Ryan, K.J. (1979) The microenvironment of the human follicle: interrelationships among the steroid levels in antral fluid, the population of granulosa cells and the status of the oocyte in vivo and in vitro. J. clin. Endocr. Metab. 49, 851-860.

McNatty, K.P., Heath, D.A., Henderson, K.M., Lun, S., Hurst, P.R., Ellis, L.M., Montgomery, G.W., Morrison, L. \& Thurley, D.C. (1984) Some aspects of thecal and granulosa cell function during follicular development in the bovine ovary. J. Reprod. Fert. 72, $39-53$.

Menezo, Y. (1976) Milieu synthétique pour la survie et la maturation des gamètes et pour la culture de l'oeuf fécondé. C. r. hebd. Séanc. Acad. Sci., Paris D 282, 1967-1970.

Menezo, Y. (1985) Milieux de culture pour la fécondation in vitro. Annls Biol. clin. 43, 27-31.

Moon, Y.S., Dorrington, J.H. \& Armstrong, D.T. (1975) Stimulatory action of follicle-stimulating hormone on estradiol-17 $\beta$ secretion by hypophysectomized rat ovaries in organ culture. Endocrinology 97, 244-247. 
Moon, Y.S., Tsang, B.K., Simpson, C. \& Armstrong, D.T. (1978) 17ß-estradiol biosynthesis in cultured granulosa and thecal cells of human ovarian follicles: stimulation by follicle-stimulating hormone. J. clin. Endocr. Metab. 47, 263-267.

Moor, R.M. (1977) Sites of steroid production in ovine Graafian follicles in culture. J. Endocr. 73, 143-150.

Moor, R.M., Hay, M.F., Dott, H.M. \& Cran, D.G. (1978) Macroscopic identification and steroidogenic function of atretic follicles in sheep. J. Endocr. 77, 309-31.8.

Orly, J., Sato, G. \& Erickson, G.F. (1980) Serum suppresses the expression of hormonally induced functions in cultured granulosa cells. Cell 20, 817-827.

Pedersen, T. (1970) Determination of follicle growth rate in the ovary of the immature mouse. J. Reprod. Fert. 21, 81-93.

Pedersen, T. (1972) Cell population kinetics of the ovary of the immature mouse after FSH stimulation. In Gonadotropin and Ovarian Development, pp. 312324. Eds W. R. Butt, A. C. Crooke \& M. Ryle. Livingstone, Edinburgh.

Pelletier, J. (1972) Dosages radioimmunologiques de la LH plasmatique ovine et bovine. In Techniques Radioimmunologiques, pp. 237-225. INSERM, Paris.

Peluso, J.J. \& Steger, R.W. (1978) Role of FSH in regulating granulosa cell division and follicular atresia in rats. J. Reprod. Fert. 54, 275-278.

Rao, M.C., Midgley, A.R. \& Richards, J.S. (1978) Hormonal regulation of ovarian cellular proliferation. Cell 14, 71-78.

Richards, J.S. (1980) Maturation of ovarian follicles: actions and interactions of pituitary and ovarian hormones on follicular cell differentiation. Physiol. Rev. 60, 51-89.

Ryle, M. (1969) A quantitative in vitro response to follicle-stimulating hormone. J. Reprod. Fert. 19, 87-94.
Ryle, M. (1972) The growth in vitro of mouse ovarian follicles of different sizes in response to purified gonadotrophins. J. Reprod. Fert. 30, 395-405.

Saumande, J., Tamboura, D. \& Chupin, D. (1985) Changes in milk and plasma concentrations of progesterone in cows after treatment to induce superovulation and their relationships with number of ovulations and of embryos collected. Theriogenology 23, 719-731.

Savion, N., Lui, G., Laherty, R. \& Gospodarowicz, D. (1981) Factors controlling proliferation and progesterone production by bovine granulosa cells in serum-free medium. Endocrinology 109, 409-420.

Thibier, M. \& Saumande, J. (1975) Oestradiol-17ß, progesterone and 17a-hydroxyprogesterone concentrations in jugular venous plasma in cows prior to and during oestrus. J. Steroid Biochem. 6, 1433-1437.

Tsonis, C.G., Carson, R.S. \& Findlay, J.K. (1984) Relationships between aromatase activity, follicular fluid oestradiol- $17 \beta$ and testosterone concentrations, and diameter and atresia of individual ovine follicles. J. Reprod. Fert. 72, 153-163.

Turnbull, K.E., Braden, A.W.H. \& Mattner, P.E. (1977) The pattern of follicular growth and atresia in the ovine ovary. Aust. J. biol. Sci. 30, 229-241.

Vendrely, C., Lageron, A. \& Tournier, P. (1970) Histoenzymological and cytophotometric studies on the variations of some enzymatic activities in different cell cycle phases in cultured cells. Expl Cell. Res. 62, 249-253.

Watson, P. (1966) A slide centrifuge: an apparatus for concentrating cells in suspension onto a microscope slide. J. Lab. Clin. Med. 68, 494-501.

Received 1 July 1986 